\title{
Muistisairaan fyysistä ja psyykkistä aktiivisuutta tukevaa asumista
}

Muistisairauksien esiintyvyys kasvaa siirryttäessä vanhimpiin ikäluokkiin, ja merkittävin riskitekijä muistisairaudelle onkin korkea ikä. Väestön ikärakenteen muutoksen seurauksena muistisairaiden lukumäärän ja suhteellisen osuuden väestöstä ennustetaankin Suomessa kasvavan ainakin vuoteen 2030 saakka. Fyysisen toimintakyvyn heikentyessä ikääntyneen on mahdollista jatkaa vielä pitkään asumista omassa kodissaan, mutta muistin heikentyminen vaarantaa sitä merkittävästi. (1.)

Väestön ikääntymisellä on vaikutusta siihen, että asuinalueiden kehittämisessä kiinnitetään yhä enemmän huomiota asuinympäristöjen muisti- ja ikäystävällisyyteen (2). Lawtonin \& Nahemowin (3) "paine-kompetenssi mallin" mukaan kompetenssin heikentyessä, esimerkiksi muistisairauden vuoksi, progressiivista heikentymistä ilmenee useissa toiminnoissa, jonka seurauksena ympäristö aiheuttaa kasvavia haasteita yksilölle ja vaikeuksia selviytyä päivittäisistä toiminnoista. Soveltamalla Powell-Lawtonin teoriaa, ulkoisen ympäristön muokkaaminen voi auttaa ylläpitämään yksilöiden maksimaalista potentiaalista toimintakykyä, tukien heidän omatoimisuuttaan ja elämänlaatuaan päivittäisessä elämässään pidempään (4).

Fyysisen ympäristön kehittämisessä muistija ikäystävällisiksi tulee myös huomioida, että asuinalueet yhteisönä tukisivat iäkkäiden ja muistisairaiden asukkaiden osallisuutta ja yhteisöön kuulumista (2). Laatusuosituksissa hyvän ikääntymisen ja palvelujen turvaamiseksi (5), osallisuus on monitasoista, kokemuksellista kuulumisen tunnetta sekä konkreettisia osallistumisen mahdollisuuksia. Asuinympäristö on yksi tärkeimmistä tekijöistä iäkkäiden ihmisten osallisuuden kannalta. Ohjeistusta on hyvin saatavilla muisti- ja ikäystävällisten asuinalueiden, rakennusten ja asuntojen suunnitteluun, mutta käytännön esimerkkejä rakennetuista ympäristöistä ei ole vielä kovin paljon. (2.)

Yksi kansainvälisesti tunnettu muistisairaiden kylä on Hogewyk Weespissä, Hollannissa, jonka kyläkonsepti poikkeaa muista muistisairaiden asumismuodoista maailmalla. Kylä oli valmistuessaan vuonna 2009 maailman ensimmäinen kylä muistisairaille. Sen kerrotaan mahdollistavan elämän viimeisten vuosien viettämisen yhteisöllisessä miljöössä, joka poikkeaa useiden hoivakotien persoonattomasta, sairaalamaisesta ja kliinisestä ympäristöstä (6). Kylä muodostuu muutamasta korttelista, jonka sisällä on ruokakauppa, ravintola, kahvila, teatteri, kuntosali, kampaamo, ja sieltä johtaa ainoastaan yksi uloskäynti ulkomaailmaan (vartioitu pyöröovi). Kylässä asuu lähemmäs 170 ikäihmistä.

EU-rahoitteisen SEMPRE hankkeen (Social Empowerment in Rural areas 2016-2019) (7) puitteissa hankkeessa työskentelevillä on ollut etuoikeus vierailla Hogewykin kylässä yhdessä Pohjanmaalla vanhustyössä toimivien kumppaneidemme kanssa.

\section{LAAJEMMAN ELINPIIRIN SÄLLYTTÄMINEN TURVALLISESSA YMPÄRISTÖSSÄ}

Iäkkäät ihmiset tarvitsevat palveluja kotiin ja palveluasumista ensisijaisesti juuri muistisairauksien vuoksi. Jo muistisairauden varhaisessa vaiheessa ympäristön tulkinta ja hallinta voi vaikeutua. Vaikka fyysinen toimintakyky voi olla pitkään hyvä, muistin heikkeneminen hankaloittaa kodin ulkopuolella liikkumista ja päivittäisiä toimia kotona. (2.) Omassa kodissa asuva muistisairas henkilö voi kokea ulkomaailman turvattomana ja eristäytyä omaan kotiinsa. Omatoimisesti ulkona liikkuvan iäkkään ihmisen avuntarvetta eivät kanssaihmiset aina huomaa. Muistisairas henkilö 
ei välttämättä löydä omaa kotia, ja hän saattaa esimerkiksi kaupunkiympäristössä eksyä kauas käyttäessään julkisia kulkuvälineitä.

Muistisairauden eteneminen johtaa usein myös tilanteeseen, jossa hyvän elämän toteutuminen ei ole enää mahdollista kotioloissa, ja vaihtoehtona on palveluasuminen. Tuttu asuinympäristö ja elinpiiri tulisi mahdollisuuksien mukaan säilyttää ja palveluasuminen sijoittaa mahdollisimman lähelle iäkkään ihmisen aikaisempaa asuinpaikkaa. Samoin tärkeää olisi palveluasumisen sijainti muun asuntokannan yhteydessä eikä muun asutuksen ulkopuolella. (2.)

\section{MUISTISAIRAIDEN KYLÄSSÄ ASUKKAAT ELÄVÄT LÄHES NORMAALIA ELÄMÄÄ}

Hogewykin kaltainen ympäristö mahdollistaa aktiivisen elämän jatkamisen turvallisessa ympäristössä. Kylän ideana on, että asukkaiden arkipäivän elämän tulisi olla mahdollisimman samakaltaista kuin aikaisemmin elämässä. Kaikilla asukkailla on pitkälle edennyt dementia, ja suurimmalle osalle kylä on heidän viimeinen asuinpaikkansa. Kylässä on lähes yhtä monta työntekijää kuin on asukasta. Työntekijät käyttävät arkivaatteita ja heiltä puuttuvat ulkoiset tunnistemerkit. Koko henkilökunta kantaa vastuuta kohtaamistaan muistisairaista, he ojentavat auttavan kätensä, mikäli muistisairas henkilö ei löydä perille, tai iäkäs henkilö kulkee liian vähissä vaatteissa alueella. Ravintolassa työskentelevät ovat myös palkattuja hoitajia, jotka toimivat sekä hoitajina, seuranpitäjinä että ravintolan henkilökuntana, ja tarjoilevat muistisairaan toiveiden mukaan sekä kahvia että viiniä.

Muistisairaiden kylän jokaisessa kodissa asuu 6-7 henkilöä. Päivisin kodissa on aina paikalla yksi henkilö, jonka tehtävänä on auttaa ja huolehtia kodissa juuri sillä hetkellä olevista, valmistaa ruokaa yhdessä iäkkäiden kanssa jne. Kylässä pyritään edistämään jatkuvuutta, joten sama henkilö tulee töihin samaan asuntoon joka päivä viikon ajan. Samanaikaisesti iäkkäät voivat liikkua vapaasti ulos ja sisään omien toiveiden mukaisesti, ja lisäksi 1-2 hoitajaa on jokaisen kodin yhteydessä auttamassa kauppaan, kuntosalille, teatteriin, ravintolaan tai muihin aktiviteetteihin tai kerhoihin. Teatteri ja ravintola ovat yleisiä tiloja, joissa kuka tahansa voi vierailla.

Myös Nordinin ym. (8) tutkimuksen perusteella iäkkäiden henkilöiden hoidon optimoi- miseksi, suunnitteluprosessissa täytyy keskittyä helppopääsyisiin ympäristöihin, jotka mahdollistavat asukkaiden itsenäisen tilojen käytön. Aikaisemmat tutkimukset korostavat tukea antavien ympäristöjen merkitystä, jotka kohtaavat hyvin hauraiden iäkkäiden ihmisten tarpeet (8-10).

Muisti- ja ikäystävällisen asuinympäristön positiivinen kehä lähtee liikkeelle asuinympäristöstä, joka on esteetön ja salliva, ja houkuttelee iäkkäitä ihmisiä ulkoilemaan ja asioimaan. Arkiliikunta puolestaan ylläpitää ja parantaa fyysistä ja psyykkistä toimintakykyä. Sen seurauksena vahvistunut toimintakyky mahdollistaa liikkumisen kauemmas asunnosta ja osallistumisen ympäristössä tapahtuvaan toimintaan. Osallistuminen aikaansaa sosiaalisten kontaktien lisääntymisen ja tukee sosiaalista toimintakykyä. Se lisää iäkkään tunnetta kuulumisesta lähiyhteisöön ja vahvistaa yhteisöllisyyttä. (2.)

Hogewykin muistisairaiden kylässä on koteja, jotka on sisustettu perinteisellä, urbaanilla tai enemmän kansainvälisellä tyylillä. Sekä sisustus, ruoka ja aktiviteetit on sovitettu määriteltyihin elämäntyyleihin siten että "perinteisessä" kodissa asuvat syövät useammin tavallista kotiruokaa, kuuntelevat perinteistä (hollantilaista) musiikkia, tv-ohjelmina kotimaisia viihdeohjelmia ja uutisia, kun taas enemmän kansainvälisesti suuntautuneet kodit valmistavat enemmän ulkomaiden inspiroimia ruokia ja katselevat kansainvälisiä elokuvia tai sarjoja tv:stä, juovat toisinaan lasin viiniä ja kodin sisustus on ylellisempi.

\section{AKTIIIISEN ELÄMÄN JATKUMINEN}

Nordinin ym. tutkimuksessa fyysisen ympäristön suunnittelulla oli merkitystä hoivakotien asukkaiden aktiviteetteihin ja vuorovaikutukseen. Yhteisölliset tilat, joita voivat käyttää eri yksiköiden asukkaat voivat rohkaista heitä lähtemään liikkeelle asunnoistaan. Iäkkäiden ihmisten pitkäaikaishoidossa päätavoite on maksimoida asukkaiden hyvinvointi ja itsenäisyys, ja siihen voidaan suuresti vaikuttaa sekä organisatorisilla tekijöillä että ympäristön huomioivilla näkökohdilla. Fyysinen ympäristö, hoitofilosofia ja -kulttuuri merkitsevät paljon hoivakodin asukkaille, ja ne vaikuttavat toisiinsa. (8.)

Tutustumiskäynnillämme Hogewykissä oppaana toimineen hoitajan mukaan hoitokoti ei ole kustannuksiltaan kalliimpi kuin muut hoitokodit. Hogewykin ja muiden muistisairaiden 
hoitokotien ero on lähinnä siinä, että iäkkäät pitkälti aktivoivat ja kuntouttavat itse itseään, kun he liikkuvat vapaasti melko suurella alueella ja osallistuvat erilaiseen toimintaan kodissa ja sen ulkopuolella. Oppaamme mukaan tämä vähentää lääkäreiden ja fysioterapeuttien tarvetta.

Iäkkäiden ihmisten fyysinen aktiivisuus on suurimmalta osalta arkipäivän toimintaa, kuten asiointia, kotitöitä ja kävelyä. Tutkimuksissa on todettu, että lyhyidenkin matkojen päivittäinen käveleminen ylläpitää toimintakykyä. Sisällä oleskelu pelkästään ei ylläpidä edes kohtalaista fyysistä aktiivisuutta. Sisällä liikkuminen on lyhytkestoista ja intensiteetiltään matalaa. Äärimmillään päivän aikana voidaan olla vain muutaman minuutin ajan liikkeellä ja muu aika kuluu paikoillaan istuen tai makuulla. Kun liikutaan ulkona, käydään tapaamassa naapureita tai lähdetään kaupungille, fyysinen aktiivisuus kasvaa verrattuna sisätiloissa oleskelupäiviin. Parhaita keinoja iäkkäiden liikunnallisen aktiivisuuden lisäämiseen voikin olla juuri tukea mahdollisuutta ulkoiluun ja asiointia kaupungilla. (11.)

Samalla muistisairaiden kylän asukkaiden läheisten on hyväksyttävä, että vapaus tuo mukanaan monia riskejä, jotka eivät ole kokonaan kontrolloitavissa. Jos ulospääsy osoittautuisi kohtalokkaaksi, täytyy läheisten voida elää uskoen, että muistisairaalle oli kuitenkin parempi olla aktiivinen niin kauan kuin mahdollista, kuin elää kauemmin kontrolloidummassa, mutta ehkä myös rajoitetummassa ympäristössä. Tämä saattaakin olla yksi syy siihen, että jono kyläasumiseen ei ole niin pitkä kuin voisi kuvitella.

\section{TAVOITTEENA MUISTI- JA IKÄYSTÄVÄLLINEN ASUINYMPÄRISTÖ}

Useissa yleisönosastonkirjoituksissa on kritisoitu iäkkäiden ihmisten kotona asumisen ideaalia erityisesti muistisairaiden kohdalla $(12,13)$. Myös tiedotusvälineissä haastateltujen asiantuntijoiden mielipiteiden mukaan kotihoitoon ei ole annettu riittävästi resursseja samalla kun hoivalaitoksia on alettu purkamaan. Ikääntyneet voivat ajoittain olla heitteillä omassa kodissaan, erityisesti kotona asuvien muistisairaiden tilanne voi olla huono. Tulevaisuudessa ympärivuorokautisia hoitopaikkoja on vähemmän, mutta kuitenkin niiden tarvitsijoita on yhä enemmän. Professori Marja Jylhän mukaan päättäjien olisi herättävä näkemään tosiasiat, sillä pelkästään kotihoitoa kehittämällä ei ikääntyneiden hoivan tarvetta ratkaista $(14,15)$.

Hemma Bäst - Kotona Paras hankkeen (16) tulosten perusteella yksilölliset erot tulisi myös huomioida paremmin niin ikääntyneiden palveluiden kuin asumisen suunnittelussa. Vaihtoehtoja asumiselle olisi tulevaisuudessa oltava lisää. Samoin iäkkäät ihmiset ovat toivoneet valinnan mahdollisuuksia asumiseen, koska ei ole olemassa mitään yhtä kaikille soveltuvaa asumisen mallia tai ideaalia (17). Yhteiskunnan taholta korostetaan entistä enemmän kansalaisten omaa vastuunottoa terveydestä, tarvittavista palveluista ja oman asuinympäristön toimivuudesta myös iäkkäänä (18). Osa ikääntyneistä kykenee suunnittelemaan ja tekemään itsenäisiä valintoja oman asumisensa suhteen. Valinnanmahdollisuuksia on paljon, erityisesti jos sosioekonominen asema on vahva, mutta valintavaihtoehdot kuitenkin yleensä supistuvat, kun hoivan ja avun tarve kasvaa. (19.)

Suomessa huolehditaan kohtuullisen hyvin muistisairaiden perustarpeista, kuten ruoasta, lääkkeistä ja hygieniasta, mutta suurempi ongelma on monen kotona asuvan vanhan ihmisen yksinäisyys ja turvattomuus. Muistisairaiden hoidosta puuttuu usein yksilöllisten tarpeiden huomioiminen ja mahdollisuus entisen elämäntyylin jatkamiseen. (20.) Ikääntyneiden asumisen suunnittelussa ei tulisi kiinnittää huomiota pelkästään "hoivaratkaisuihin, vaan iäkkäät ihmiset olisi nähtävä heterogeenisena ryhmänä. Iäkkään ihmisen terveydentilasta riippumatta, on heillä jokaisella omat tarpeensa, toiveensa, elämäntyylinsä, joihin tulisi kiinnittää entistä enemmän asumisratkaisuissa huomiota. $(21,22$.) Hogewykissä myös näihin asioihin on kiinnitetty huomiota. Kylän jokainen koti on muokattu jonkin teeman mukaisesti, joka yhdistää samassa yhteisössä asuvia lähtien heidän aikaisimmista kokemuksistaan ja elämäntyylistään. Asumisen yhdessä samanhenkisten kanssa oletetaan vahvistavan turvallisuuden ja yhteenkuuluvuuden tunnetta, ja lisäävän mahdollisuuksia, että asukkaat löytävät yhteisiä nimittäjiä yhteisissä askareissaan ja aktiviteeteissaan.

Ikä- ja muistiystävällisyys liitetään nykyisin asuinympäristöjen kehittämiseen. Tavoitteena on tarjota iäkkäille ja muistisairaille soveltuvia asumisratkaisuja, jotka tukevat ikäihmisten mahdollisuutta aktiivisuuteen, hyvinvointiin ja turvallisuuteen (2). 
Suomessakin on viime vuosina aloitettu mielenkiintoisia asumisen kehittämisen hankkeita, kuten useilla paikkakunnilla toteutettavat palveluja yhteisökorttelit ikääntyneiden asumisratkaisuina (23). Ageing in place- periaate nähdään ny- kyisin monimuotoisemmin ja laajemmin $(21,22)$, jolloin omassa kodissa asuminen ei ole ainoa paikallaan ikääntymisen muoto, vaan se tarkoittaa myös muuttamista asuinympäristöön, joka tukee omatoimisuutta ja osallisuutta yhteisössä.

\section{LÄHTEET}

(1) Turvallisia vuosia ikääntyneille. Selvitys ikääntyneiden turvallisuustilanteesta Suomessa. Sisäasiainministeriön julkaisuja 27/2012, 21-23. Luettu 12.4.2019. http://julkaisut. valtioneuvosto.fi/bitstream/handle/10024/79432/ sm_272012.pdf

(2) Rappe, E, Kotilainen H, Rajaniemi J, Topo P. 2018. Muisti- ja ikäystävällinen asuminen ja asuinympäristö. Ympäristöopas 2018. Helsinki: Ympäristöministeriö. Luettu 27.3.2019. http://urn.fi/URN:ISBN:978-952-11-4806-4

(3) Lawton MP, Nahemow L. Ecology and the aging process. Kirjassa: Eisdorfer C, Lawton MP. (toim.) The psychology of adult development and aging. Washington, DC, US: American Psychological Association 1973, 619-674.

(4) Woodbridge R, Sullivan MP, Harding E, ym. Use of the physical environment to support everyday activities for people with dementia: A systematic review. Dementia 2018;17:533-572. https://doi.org/10.1177\%2F1471301216648670

(5) Laatusuositus hyvän ikääntymisen turvaamiseksi ja palvelujen parantamiseksi. Sosiaali- ja terveysministeriön julkaisuja 2013:11. Helsinki 2013. http://julkaisut. valtioneuvosto.fi/bitstream/handle/10024/69933/ ISBN_978-952-00-3415-3.pdf

(6) Haeusermann T. The Dementia Village: Between Community and Society. Kirjassa: Krause F, Boldt FJ. (toim.) Care in Healthcare. Cham: Palgrave Macmillan, 2018, 135-167. Luettu 7.3.2019. https://link.springer.com/ chapter/10.1007/978-3-319-61291-1_8

(7) Häggström U, Jungerstam S, Wentjärvi A. Empowerment of older adults. IkäNYT! 2/2018. Luettu 7.3.2019. http://www.karelia. fi/ikanyt/2018/02/15/empowerment-of-olderadults/

(8) Nordin S, McKee K, Wallinder M, ym. The physical environment, activity and interaction in residential care facilities for older people: a comparative case study. Scand J Caring Sci. 2017;31:727-738.

https://doi.org/10.1111/scs.12391

(9) Iwarsson S, Stahl A. Accessibility, usability and universal design-Positioning and definition of concepts describing person-environment relationships. Disabil Rehabil. 2003; 25:57-66. https://doi.org/10.1080/0963828021000007969

(P-E) fit and activity of daily living (ADL) dependence of older Swedish adults. Arch Gerontol Geriatr. 2009;49:e16-22. https://doi.org/10.1016/j.archger.2008.08.001

Rantanen T. Iäkkäiden ihmisten elinpiiri. Kirjassa: Häkli J, Vilkko R, Vähäkylä L. (toim.) Kaikki kotona? Asumisen uudet tuulet. Helsinki: Gaudeamus; 2015, 93-102.

(12) Silvennoinen O. "Kuka suojelisi vanhusta hänen omilta toiveiltaan?" Helsingin Sanomat, mielipide, 14.2.2016. http://www.hs.fi/mielipide/a1455334301507

(13) Röntynen L. "Muistisairaiden itsemääräämisoikeutta kunnioitetaan aivan liikaa” Helsingin Sanomat, mielipide, 14.2.2016. http://www.hs.fi/paivanlehti/14022016/ a1455334166245

(14) Honka N. "Ei minua uskottu, kun sanoin, ettei äiti pärjää enää kotona"-Tutkija: Vanhusten omaan tahtoon vedotaan Suomessa irvokkaalla tavalla". Yle uutiset 19.11.2017. https://yle.fi/uutiset/3-9932949

(15) Mölsä A. Oikeusoppineet: Vanhusten lisääntynyt kotihoito on johtanut heitteillejättöihin. Yle uutiset 22.4.2018. https://yle.fi/uutiset/3-10172017

(16) Peltomäki P, Palosaari S. Stödja och främja äldre personers hemmaboende enligt diskussioner med äldre, närståendevårdare och professionella. Kirjassa: Hietanen A, Fröjdö M. (toim.) Hemma Bäst - Kotona Paras. Med focus på äldres trygga och säkra hemmaboende. Novia Publikation och production, serie R: Rapporter, 5/2016, 38-42. http://urn.fi/ URN:ISBN:978-952-7048-37-5

(17) Wiles JL, Leibing A, Guberman N, ym. The meaning of "Aging in Place" to older people. Gerontologist. 2011;52:357-366. https://doi.org/10.1093/geront/gnr098

(18) Välikangas K. Kuntien toiminta ikääntyneiden kotona asumisen tukemisessa ja elinympäristöjen kehittämisessä. Teoksessa R. Hynynen (toim.) Ikääntyneiden asumistarpeisiin varautuminen kunnissa. Ympäristöministeriön raportteja 4/2017, 24. http://urn.fi/ URN:ISBN:978-952-11-4726-5

(19) Juhila O, Kröger T. Onko vanhalla vara valita? Vanhojen ihmisten uudet asumisvaihtoehdot. Kirjassa: Häkli J, Vilkko R, Vähäkylä L. (toim.) Kaikki kotona? Asumisen uudet tuulet. Helsinki: Gaudeamus 2015; 82-92. S. A 10-year follow-up study on subjective wellbeing and relationships to person-environment 
(20) Juva K. Muistisairaiden asumisesta - jokaiselta kykyjensä mukaan, jokaiselle tarpeidensa mukaan, Duodecim 2014;130, 2382-3. Luettu 22.3.2019. https://www.duodecimlehti.fi/ lehti/2014/22/duo11978

(21) Jolanki O. Liian vanha vai liian nuori muuttamaan? Iän merkitys asumisen valinnoissa. Kirjassa: Juhila K, Kröger T. (toim.) Siirtymät ja valinnat asumispoluilla. SoPhi. Jyväskylän yliopisto 2016. Luettu14.2.2019. http://urn.fi/ URN:ISBN:978-951-39-6664-5

(22) Mikkola T, Heitto M, Rahikka A. Palvelualueet ikääntyneiden asumisen kehittämisessä. Kirjassa: Hynynen R. (toim.) Palvelualueen ja ikäystävällisen asuinalueen kehittäminen. Ympäristöministeriön raportteja 5/2015. Luettu 6.5.2019. https://www.ymparisto.fi/ fi-FI/Asuminen/Ikaantyneiden_asuminen/ Palvelualueen_ja_ikaystavallisen_asuinal(32990)
(23) Oosi O, Koramo M, Sadeoja S. Ikääntyneiden palvelu- ja yhteisökorttelin toteuttaminen. Asumisen rahoitus- ja kehittämiskeskuksen raportteja 1/ 2019. Luettu 9.5.2019 https:// www.ara.fi/fi-FI/Tietopankki/Julkaisut/ARAn raportteja_julkaisusarja/Ikaantyneiden_palvelu ja_yhteisokortteli(49511)

\author{
Anne Hietanen \\ TtM \\ Projektitutkija \\ Yrkeshögskolan Novia \\ SUSANNE JUNGERSTAM \\ VTT \\ Yliopettaja \\ Yrkeshögskolan Novia
}

